\title{
New Findings on the Fiscal Impact of Immigration in the United States
}

Pia Orrenius

Federal Reserve Bank of Dallas Research Department Working Paper 1704 


\title{
New Findings on the Fiscal Impact of Immigration in the United States*
}

\author{
Pia Orrenius \\ Federal Reserve Bank of Dallas \\ 2200 N. Pearl St. \\ Dallas, TX 75201 \\ 214-922-5747 \\ Pia.Orrenius@dal.frb.org
}

April 2017

\begin{abstract}
The National Academies of Sciences, Engineering, and Medicine (2016) report on the economic and fiscal effects of immigration included the first set of comprehensive fiscal impacts published in twenty years. The estimates highlight the pivotal role of the public goods assumption. If immigrants are assigned the average cost of public goods, such as national defense and interest on the debt, then immigration's fiscal impact is negative in both the short and long run.

However, marginal cost calculations are more relevant for policy decisions, and the report shows that if immigrants are assigned the marginal cost of public goods, then the long-run fiscal impact is positive and the short-run effect is negative but very small (less negative than that of natives). Moreover, highly-educated immigrants confer large positive fiscal impacts, contributing far more in taxes than they consume in public benefits. To the extent that immigrants impose net costs, these are concentrated at the state and local level and are largely due to the costs of public schooling.
\end{abstract}

JEL Codes: J15, H50, H72

Keywords: immigration; fiscal impact; public goods

\footnotetext{
* I thank Kim Reuben and Chris Mackie for helpful comments. The views expressed here are solely those of the author and do not reflect those of the Federal Reserve Bank of Dallas or the Federal Reserve System.
} 


\section{New Findings on the Fiscal Impact of Immigration in the United States}

Despite the post-recession stagnation of immigrant inflows to the United States, the debate over the costs and benefits of immigration has grown more intense. Some critics focus on issues that have little to do with economics, such as the impact of immigration on culture or national identity. Others have zeroed in on the economic effects, including the labor market effects of immigration, i.e. its impact on the wages and employment of native workers, and the fiscal impact, i.e. its impact on government revenues and expenditures.

There have been far more labor market studies of immigration than fiscal studies. ${ }^{1}$ And many of the fiscal studies that exist have been poorly done, offering incomplete or misleading estimates of the fiscal effects of immigration. In this vein, the recently published report The Economic and Fiscal Consequences of Immigration by the National Academies of Sciences, Engineering and Medicine (2016), hereafter NAS, represents an important and timely contribution. ${ }^{2}$

\section{What is the fiscal impact and how is it measured?}

Immigrants, much like natives, contribute taxes in a number of ways; they pay taxes on earnings, including income and payroll taxes, on purchases (sales taxes), on housing (property tax), on motor vehicles (registration fees), and so on. Similar to natives, immigrants typically also consume at least some government-provided services, which may include public schools for their children, subsidized health care in the form of Medicaid and/or Medicare, income support

\footnotetext{
${ }^{1}$ For a summary of the economic effects of immigration, see Orrenius and Zavodny (2012).

${ }^{2}$ I was a member of the panel that directed and co-wrote the 2016 report along with Francine Blau, Michael BenGad, George Borjas, Christian Dustman, Barry Edmonston, Isaac Ehrlich, Charles Hirschman, Jennifer Hunt, Dowell Myers, Jeff Passel, Kim Reuben, Marta Tienda and Yu Xi. Chris Mackie was study director. See https://www.nap.edu/read/23550/chapter/1 for a full list of the contributors.
} 
programs such as the Earned Income Tax Credit, and welfare programs such as Temporary Assistance for Needy Families (TANF) or the Women and Infant Children (WIC) program, and Social Security. It bears noting that unauthorized immigrants are not eligible for most welfare programs, including TANF, and there are restrictions on the eligibility for some legal immigrants as well. Immigrants also rely on publicly provided services such as police and fire protection.

The characteristics of immigrants, such as their age, earnings and family size, will be key to determining how much they fiscally contribute and receive. The progressivity of the tax system and the generosity of public programs will also play a role. Tax and benefit systems, as well as the characteristics of immigrants, vary greatly across states, which suggests the fiscal impacts of immigration may also be different across states. ${ }^{3}$

Other considerations are also key to determining fiscal effects, particularly the time horizon over which revenues and expenditures are measured. Cross-sectional or static short-run estimates look at individuals (or households) at a point in time. While this is a transparent method, it ignores the crucial role played by age and time in the United States. Dynamic or long-run estimates are much more representative of an immigrant's complete fiscal impact because tax contributions and government benefits are typically measured over an entire lifetime and will include the contributions of his descendants. The downside to dynamic estimates however is that projecting income and benefits into the future requires making many assumptions. The 2016 NAS report presents both static (short-run) and dynamic (long-run) estimates. ${ }^{4}$

\footnotetext{
${ }^{3}$ Chapter 9 of the 2016 NAS report presents estimates of the fiscal impact by state.

${ }^{4}$ See Chapter 7 of the 2016 NAS report for a detailed discussion of the two methods and related assumptions.
} 


\section{Past Estimates of Immigration's Fiscal Impact}

Before the 2016 NAS report, most scholars cited the fiscal estimates in the National Research Council report The New Americans: Economic, Demographic and Fiscal Effects of Immigration (1997). The 1997 report found that, over their lifetimes, low-educated immigrants, those with a high school diploma or less, impose a net fiscal cost while high-educated immigrants, those with a college degree or higher, represent a net fiscal benefit. ${ }^{5}$ Using a similar dynamic methodology, Lee and Miller (2000) found that the initial fiscal impact of immigrants and their households is negative due to their low initial earnings and the costs of schooling their children. However, after about 16 years, the impact of a representative immigrant turns positive.

Another finding of the 1997 NRC report, which was later reinforced by updated analysis in Lee and Miller (2000), showed that immigration's fiscal impact is typically negative at the state and local level but positive at the federal government level. A key reason is that state and local governments bear the bulk of education costs, which immigrants disproportionately incur because they have more children and lower education and incomes than natives.

\section{New Fiscal Estimates of Immigration: Static and Dynamic}

The cross-sectional fiscal impact estimates from the 2016 NAS report are shown in Table 1, which replicates two scenarios from the 2016 report—namely, one in which immigrants are assigned the average cost of public goods (top rows), and another in which immigrants are assigned the marginal cost of public goods (bottom rows). ${ }^{6}$ Public goods include the cost of

\footnotetext{
${ }^{5}$ Immigrants with less than a high school education were found to cost $\$ 89,000$ more (based on 1996 estimates) than they contribute in taxes over their lifetimes, whereas immigrants with more than a high school education were found to contribute $\$ 105,000$ more in taxes than they use in public services.

${ }^{6}$ Tax contributions and benefits receipts are based on data from the March CPS.
} 
national defense, interest on the national debt and foreign aid, among other shared expenses. ${ }^{7}$

The columns reflect three groups: immigrants and their minor children or 'dependents' ('first generation”), the adult children of immigrants and their dependents (“second generation”), and other U.S.-born adults and their dependents (“third generation”). ${ }^{8}$ This methodology assigns parents the education expenses of their children; in the case of immigrants, the returns to this investment in education (which mainly take the form of higher tax payment resulting from higher earnings) is thus attributed to the second generation. The rows in Table 1 also break the total effect into fiscal impacts at the federal versus state and local government level.

Table 1

Net Per Capita Fiscal Impacts of First, Second, and Third-plus Generations in 2013, by Public Goods Scenario and Level of Government

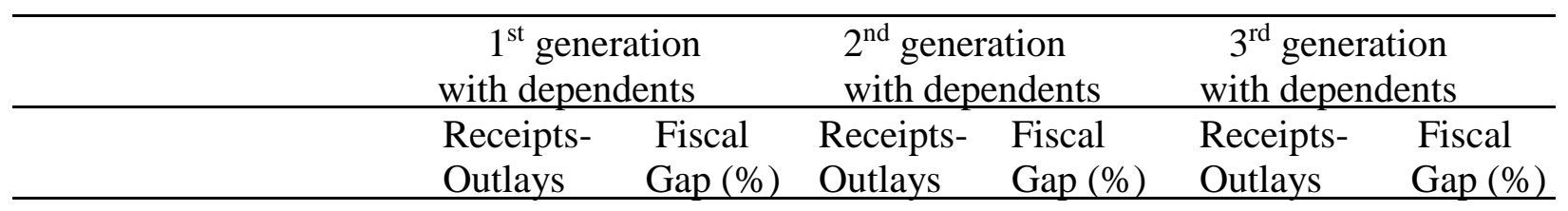

\section{Scenario 1:}

immigrants

assigned

Federal $\quad-\$ 2,650$

$27.1-\$ 3,598$

27.5

$-\$ 2,577$

21.4

avg. cost of

State\&local - $\$ 2,372$

$38.6-\$ 1,062$

17.4

$-\$ 1,031$

17.7

public goods

$-\$ 5,021$

$31.6 \quad-\$ 4,660$

24.3

$-\$ 3,608$

20.2

Scenario 2:

immigrants

assigned

\section{Federal}

$\$ 963$

$-15.7$

$-\$ 4,239$

30.9

$-\$ 3,218$

25.4

marginal cost Total

$31.7 \quad-\$ 1,177$

18.9

$-\$ 1,146$

19.2

of public goods

$-\$ 782$

$6.7-\$ 5,415$

27.1

$-\$ 4,364$

23.4

Source: Cross-sectional fiscal estimates based on The Economic and Fiscal Consequences of Immigration, Table 8-2, p. 312. Fiscal gap is defined as 1 minus receipts/outlays. Scenario 2 corresponds to scenario 5 in the NAS report.

\footnotetext{
${ }^{7}$ Public goods, defined in this way, accounted for one-third of total federal spending in 2013.

${ }^{8}$ Some immigrants' dependents are U.S.-born; in addition, some young adults who are students with very low incomes are also included as dependents.
} 
It is notable that, with one exception, every generation, immigrant and native, at every level of government, consumes more in public benefits than they contribute in taxes. Because the nation is running a sizable deficit, the entire public represents a net cost on average. Fiscal impacts are negative in every case except immigrants in the second scenario at the federal level. In the 'total' row, the fiscal gap in funding varies from a low of 6.7 percent for the first generation to a high of 32 percent also for the first generation.

The assumption about how to assign the costs of public goods makes a big difference in evaluating the fiscal impact of immigrants. Although the 2016 NAS report does not indicate a preferred or baseline specification, the marginal cost assumption is clearly the most relevant for future policy decisions because it represents the incremental effect of immigrants on public goods spending.

It is clear from Table 1 that the fiscal funding gap for immigrants is most acute at the state and local government level. As noted above, this is primarily due to the costs of public education; immigrant families in the United States have more children than do native families, which drives up their costs at the state and local level relative to non-immigrants. The offset, the higher incomes and tax contributions of their children, is attributed to the second generation. Immigrants' lower income also means they pay less in taxes on average than natives.

As discussed above, cross-sectional or static fiscal estimates like those presented in Table 1 are inherently limited by a number of shortcomings, including not controlling for differences in age between the foreign born and native born populations at a point in time, and hence should be 
used with great caution. Long-run or lifetime estimates are preferred when, for example, evaluating fiscal impacts for the purpose of formulating immigration policy. The 2016 NAS report's long-run fiscal estimates are presented in Table 2 and broken down for two sets of immigrants - those who arrived recently (in the last 5 years) and all immigrants. As before, we show the fiscal impact with and without assigning immigrants the cost of public goods. The top row is the weighted average of the remaining rows, which show fiscal impacts by education level of the immigrant and his dependents. Education level is a key determinant of income, so it will be an effective predictor of fiscal impact.

Table 2

Dynamic 75-year Per Capita Net Fiscal Impacts for Recent and All Immigrants, by Public Goods Scenario and Education Level (2012 dollars)

\begin{tabular}{lcccc}
\hline Education level & \multicolumn{2}{c}{ Recent immigrants } & \multicolumn{2}{c}{ All immigrants } \\
& No public goods & Public goods & No public goods & Public good \\
\hline Average & 259 & 173 & 58 & -5 \\
& & & & \\
Less than high school & -117 & -200 & -196 & -259 \\
High school degree & 49 & -33 & -47 & -109 \\
Some college & 261 & 170 & 99 & 34 \\
College degree & 481 & 395 & 280 & 216 \\
More than college degree & 812 & 726 & 547 & 485
\end{tabular}

Source: Estimates from The Economic and Fiscal Consequences of Immigration, Table 8-12, p. 341. Net present values are in thousands of 2012 dollars; forecast is based on the CBO long-term budget outlook. Includes taxes and expenditures at the federal, state and local level for an individual and his dependents.

Table 2 shows that in dynamic, long-run scenarios, the present value of the net fiscal impact of immigration is typically positive and can be quite large. If we assume that an additional immigrant does not increase spending on public goods, which is a reasonable assumption, a new immigrant represents a positive fiscal contribution with a net present value of $\$ 259,000$. A recent immigrant has a much larger positive fiscal impact than does an immigrant who reflects the 
characteristics of the population of all immigrants $(\$ 58,000)$. The difference is due to the fact that the stock of all immigrants has, on average, less education and is older than recent immigrants. The rise over time in education levels among U.S. immigrants partly reflects the rise in employment-based immigration in the post-1990 era and the more recent decline in lowskilled immigration.

Some of the estimates are truly astounding. A representative recent immigrant with more than a college degree contributes over $\$ 800,000$ to government coffers on net over a 75 -year period. In contrast, a typical recent immigrant who lacks a high school diploma represents a net cost of about $\$ 117,000$ dollars. Interestingly, this net cost does not reflect disproportionate outlays as compared with similar natives. Table 3 shows the difference in net fiscal 75-year impacts of immigrants versus natives by education level. Although low-skilled immigrants impose a net fiscal cost, apparent in Table 2, the net fiscal cost of natives of similar education is far larger. For example, the difference is on the order of $\$ 200,000$ less in fiscal cost of an immigrant who lacks a high school diploma versus a high school dropout native. The only education category where immigrants impose a smaller (in this case, less positive) fiscal benefit than natives is among those with bachelor's degrees. 


\section{Figure 1}

Immigrant-Native Difference in 75-year Dynamic Net Fiscal Impact, by Public Goods Scenario and Education Level

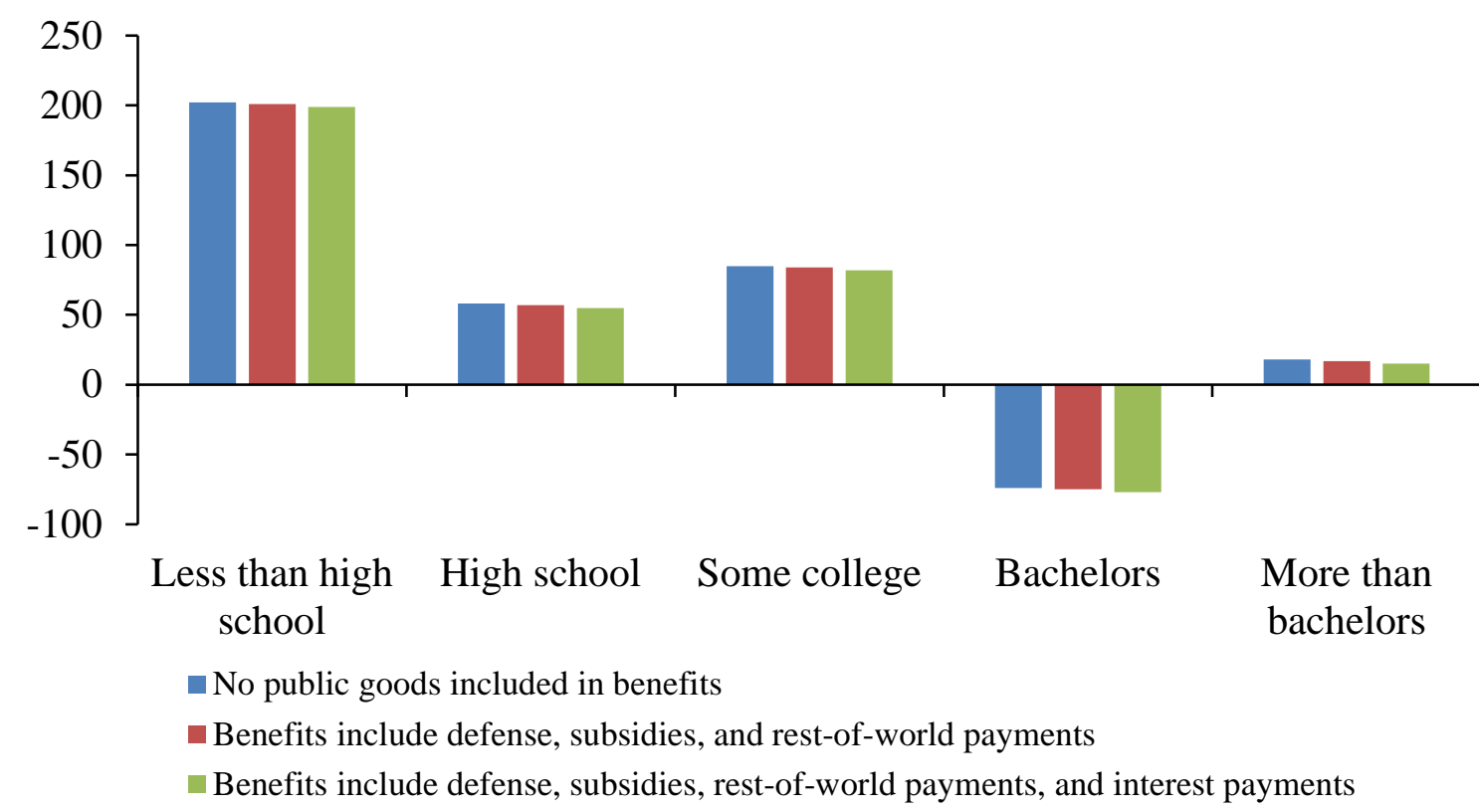

Source: Estimates from The Economic and Fiscal Consequences of Immigration, Table 8-13, pages 345346.

\section{Conclusion}

New estimates of the fiscal impact of immigration reflect some of what was already known while also highlighting some important new findings. Cross-sectional estimates based on 2013 CPS data suggest that immigrants represent a net fiscal drain on average. However, so does everyone else, including natives. When immigrants are assigned the marginal cost of public goods, their fiscal impact is actually significantly less negative than that of natives. Immigrants’ tax contributions cover 93 percent of their publicly provided benefits while natives’ contributions cover only 77 percent of theirs. The dreary overall fiscal scenario is due to large public deficits and high national debt; problems that were much less pronounced in the 1997 report. In addition, natives have grown more costly over time because they have become an older population; their 
health costs impose a disproportionate burden on the federal government because it pays for Medicare and subsidizes related expenses such as nursing homes. Meanwhile, immigrants are more costly than natives at the state and local level because they have lower incomes and more minor children; this means immigrants are particularly burdensome to state and local governments which pay for public schools.

The long-run, dynamic estimates of immigration's fiscal impact are both far more positive and also arguably more relevant, at least from a policy perspective. Recent immigrants represent a large fiscal boon because they are projected to pay much more in taxes than they use in benefits over the next 75 years. Even low-skilled immigrants, those without any college education, while they impose a net long-run cost, they are far less costly than similarly-educated natives.

The overall results of the 2016 NAS report suggest that the rise of high-skilled immigration and more recent decline in low-skilled immigration is resolving some of the most pressing concerns around immigration's fiscal impact. Since present trends are likely to continue and possibly intensify in future immigration flows, immigration may increasingly be seen as a fiscal boon rather than a burden. Immigration may even play a part in future plans to address the nation's looming fiscal shortfalls. 


\section{References}

Lee, R. and Miller, T. 2000. “Immigration, Social Security, and Broader Fiscal Impacts.” American Economic Review: Papers and Proceedings, 90(2), pp. 350-354.

National Academies of Sciences, Engineering and Medicine. 2016. The Economic and Fiscal Consequences of Immigration. Panel on the Economic and Fiscal Consequences of Immigration, F. Blau and C. Mackie (Eds.). Committee on National Statistics, Division of Behavioral and Social Sciences and Education. Washington, DC: The National Academy Press.

National Research Council. 1997. The New Americans: Economic, Demographic and Fiscal Effects of Immigration. Panel on the Demographic and Economic Impacts of Immigration, J.P. Smith and B. Edmonston (Eds.). Washington, DC: The National Academy Press.

Orrenius, P. and Zavodny, M. 2012. “Economic Effects of Migration: Receiving States.” The Oxford Handbook of The Politics of International Migration, Marc R. Rosenblum and Daniel J. Tichenor, eds., Oxford University Press. 